\title{
Changes in Surface Properties of Developing Zoospores of Blastocladiella emersonii: Binding of Concanavalin A
}

\author{
By C. J. JEN AND A. HAUG \\ MSU-DOE Plant Research Laboratory, Michigan State University, \\ East Lansing, Michigan 48824, U.S.A.
}

(Received 1 February 1979; revised 15 May 1979)

\begin{abstract}
Binding of concanavalin A to the cell surface of developing Blastocladiella emersonii zoospores was explored by fluorescence microscopy, electron microscopy and radioactive labelling. After labelling with fluorescein isothiocyanate-conjugated concanavalin $\mathrm{A}$, the fluorescence intensity of individual non-induced zoospores varied greatly. On the other hand, similarly labelled zoospores, induced with $\mathrm{K}^{+}$ions for synchronous development, revealed a more even distribution of fluorescence intensity. The zoospore surface contained $4.3 \times 10^{7}$ concanavalin A binding sites per cell which were randomly distributed and closely attached to the surface. The affinity constants ranged from $7 \cdot 5 \times 10^{7} \mathrm{M}^{-1}$ to $3.5 \times 10^{5} \mathrm{M}^{-1}$, while the Scatchard plot was typical of heterogeneous binding. Further developed cells, round cells and germlings contained $3 \cdot 0 \times 10^{7}$ to $2 \cdot 1 \times 10^{7}$ concanavalin A binding sites per cell which were mostly loosely associated patches protruding into the extracellular region. The affinity constants decreased appreciably compared with those measured at the zoospore stage. Specific concanavalin A binding characteristics appeared to correlate with the respective developmental stage of the zoospore.
\end{abstract}

\section{INTRODUCTION}

The life cycle of Blastocladiella emersonii, an aquatic unicellular fungus, constitutes a suitable eukaryotic model to investigate developmental processes (Lovett, 1975). The nongrowing, motile zoospore of B. emersonii exhibits pronounced morphological alterations, in particular at the cell surface, while undergoing encystment and germination. The zoospore loses its motility and becomes adhesive, changes extensively in fine structure, retracts the flagellum into the main body and gradually deposits material on the cell surface for primary cell wall formation. Subsequently, a germ tube emerges from the cell and this later turns into a branched rhizoidal system. The entire process takes less than $30 \mathrm{~min}$ under favourable conditions and precedes de novo protein and RNA synthesis (Soll \& Sonneborn, 1971).

Lectins are valuable tools for probing surface properties of various cell types (Gremo et al., 1978; Sharon \& Lis, 1975; Weeks, 1975). To obtain some insight into developmental alterations on the zoospore surface, concanavalin A (Con A) was employed. Recently, we have observed that Con A binding induced lysis of B. emersonii zoospores but not of round cells (Jen \& Haug, 1979). In this paper, we report zoospore surface changes as monitored by Con A binding parameters. We used $\left[{ }^{3} \mathrm{H}\right] \mathrm{Con} A$, fluorescein isothiocyanate-conjugated Con A (FITC-Con A) and ferritin-Con A. 


\section{METHODS}

Reagents. Con A and $\alpha$-methyl-D-mannoside were purchased from Sigma, FITC-Con A and ferritin-Con A were from Miles-Yeda, $\left[{ }^{3} \mathrm{H}\right]$ acetic anhydride was from Amersham/Searle, pronase was from Calbiochem, and 2,5-diphenyloxazole (PPO) and 1,4-bis-[2-(5-phenoxazolyl)]benzene (POPOP) from Research Products International Corp. (Elk Grove Village, Ill., U.S.A.).

Organism and culture conditions. The aquatic fungus $B$. emersonii was grown in standard Petri dishes at $22^{\circ} \mathrm{C}$ on Difco PYG agar. Zoospores were harvested approximately $20 \mathrm{~h}$ after inoculation by flushing individual Petri dishes with $2 \mathrm{ml}$ sporulation solution [5 mM-morpholinopropanesulphonic acid (MOPS),

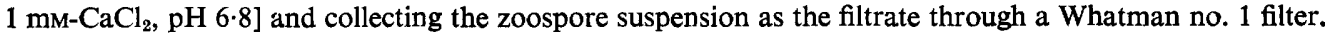
To induce synchronous zoospore germination, the procedure described by Soll et al. (1969) was followed. The zoospore suspension was incubated for $30 \mathrm{~min}$ at $27^{\circ} \mathrm{C}$, then mixed with 5 vol. germination solution ( $5 \mathrm{~mm}-\mathrm{MOPS}, 1 \mathrm{mM}-\mathrm{CaCl}_{2}, 10 \mathrm{~mm}-\mathrm{MgCl}_{2}, 50 \mathrm{mM}-\mathrm{KCl}, \mathrm{pH} 6.8$ ) at $27^{\circ} \mathrm{C}$. The cells underwent transformation from zoospores to round cells, and finally to germlings. Samples were taken from the suspension during the developmental process and fixed immediately in $1.5 \%(\mathrm{v} / \mathrm{v})$ glutaraldehyde at $22{ }^{\circ} \mathrm{C}$ for $2 \mathrm{~h}$. The cell phenotypes at the different developmental stages could be easily distinguished by light microscopy. Cells were washed three times with $0 \cdot 1 \mathrm{M}$-sodium phosphate buffer, $\mathrm{pH} 7 \cdot 2$, containing $0 \cdot 1 \mathrm{M}-\mathrm{NaCl}$.

Binding of $\left[{ }^{3} \mathrm{H}\right]$ Con $A$ to cells. $\left[{ }^{3} \mathrm{H}\right]$ Con A [specific activity 1000 c.p.m. ( $\mu$ g protein $\left.)^{-1}\right]$ was prepared using $\left[{ }^{3} \mathrm{H}\right]$ acetic anhydride (Gunther et al., 1973). Cells $\left(1 \times 10^{7}\right)$ were incubated for $2 \mathrm{~h}$ with [ $\left.{ }^{3} \mathrm{H}\right] \mathrm{Con} \mathrm{A}$ in $1.0 \mathrm{ml}$ $0.1 \mathrm{M}$-sodium phosphate buffer, $\mathrm{pH} 7 \cdot 2$, containing $0.1 \mathrm{M}-\mathrm{NaCl}$ and $0.1 \%(\mathrm{w} / \mathrm{v})$ bovine serum albumin. For control experiments, $0 \cdot 1 \mathrm{M}-\alpha$-methyl-D-mannoside was present in the reaction mixture. Cells were collected on a Whatman GF/C glass-fibre filter and washed five times with $5 \mathrm{ml}$ phosphate buffer supplemented as above. After drying overnight, the filters with the cells were placed in $10 \mathrm{ml}$ liquid scintillation solution (4 $\mathrm{g}$ PPO and $0.05 \mathrm{~g}$ POPOP per 1 toluene). Radioactivity was measured with a Packard Tricarb scintillation counter (model 3390).

Labelling of cells with FITC-Con A and quantitative fluorescence measurements. Cells $\left(2 \times 10^{6}\right)$ were incubated in $1 \mathrm{ml}$ sodium phosphate buffer, $\mathrm{pH} 7 \cdot 2$, containing $0.1 \mathrm{M}$-mannitol, $0.1 \%(\mathrm{w} / \mathrm{v})$ bovine serum albumin and $200 \mu \mathrm{g}$ FITC-Con A. For controls, 0.1 M- $\alpha$-methyl-D-mannoside was substituted for mannitol. After incubation at $22{ }^{\circ} \mathrm{C}$ for about $20 \mathrm{~min}$, the cells were washed with the above reaction mixtures, but without FITC-Con A. The cells carrying the fluorescence label were viewed under a Leitz Orthomat-W microscope with an automatic camera. Fluorescence intensity of individual cells was determined with a Leitz photometer attached to the microscope.

Ultrastructural localization of Con A receptor sites. Fixed cells were incubated with $1 \mathrm{mg}$ ferritin-Con A ml-1 at $22{ }^{\circ} \mathrm{C}$ for $30 \mathrm{~min}$, then washed with phosphate buffered saline and postfixed with $2 \%(\mathrm{w} / \mathrm{v}) \mathrm{OsO}_{4}$ in phosphate buffer. The samples were washed, dehydrated and finally embedded in Spurr's resin (Spurr, 1969). Cells incubated in the presence of $0.1 \mathrm{M}$ - $\alpha$-methyl-D-mannoside served as controls. Thin sections, without heavy metal staining, were viewed under a Siemens Elmiskop I electron microscope.

\section{RESULTS}

\section{Number and affinity of $\left[{ }^{3} \mathrm{H}\right]$ Con $A$ binding sites at the surface of $B$. emersonii}

Specific Con A binding sites are those from which the bound lectin can be removed with $\alpha$-methyl-D-mannoside as the hapten. Specific binding was determined by subtracting the contribution of non-specific binding from the total binding. The Con A binding sites at the zoospore surface appeared to be mostly specific. At worst, in the case of germlings, nonspecific binding could account for as much as $25 \%$ of the total binding at high lectin concentrations. To ascertain the number and affinity of Con A binding sites, cells were incubated with various concentrations of $\left[{ }^{3} \mathrm{H}\right]$ Con A. Results are presented in a Scatchard plot (Fig. 1). Assuming only two binding systems (Rosenthal, 1967), high and low association constants and the total number of binding sites per cell were calculated (Table 1).

The non-induced zoospore surface area was estimated as $250 \mu \mathrm{m}^{2}$ from the known size of the cell body (Lovett, 1975), an ellipsoid $(7 \times 9 \mu \mathrm{m})$, and the cylindrical flagellum $(15 \times$ $0.2 \mu \mathrm{m}$ ), and so the site density was calculated to be $1.7 \times 10^{5}$ receptors per $\mu \mathrm{m}^{2}$.

During the developmental process, when zoospores round up and germinate, a gradual decrease of Con A binding was observed. High and low association constants decreased by factors of 6 and $1 \cdot 5$, respectively, comparing non-induced zoospores with those within $15 \mathrm{~min}$ 


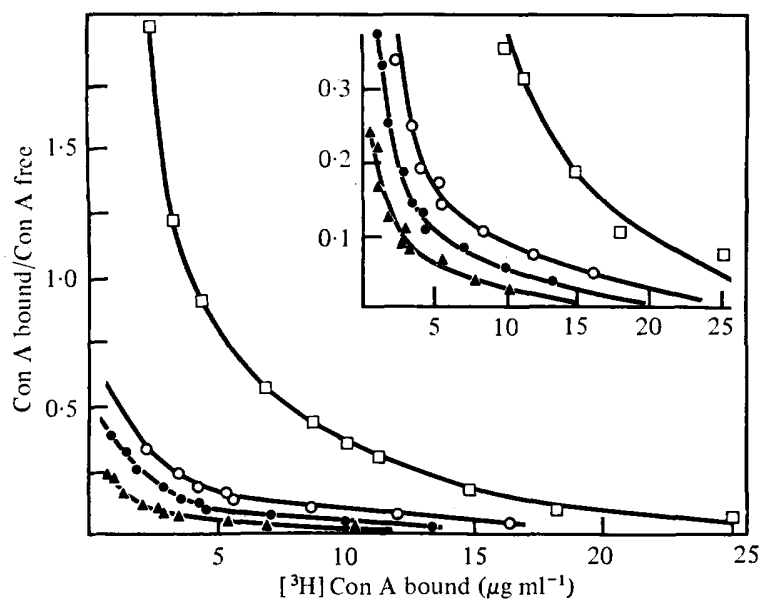

Fig. 1. Scatchard plot of specific concanavalin A binding to B. emersonii cells during encystment: $\square$, non-induced zoospores; $\bigcirc, 60 \%$ zoospores and $40 \%$ round cells, $15 \mathrm{~min}$ after induction; , $5 \%$ zoospores, $70 \%$ round cells and $25 \%$ germlings, 30 min after induction; $\Delta, 2 \%$ zoospores, $14 \%$ round cells and $84 \%$ germlings, $45 \mathrm{~min}$ after induction. Cells were derived from the same batch. Except for non-induced cells $(\square)$, all other cells were induced to germinate. Inset: lower part of the figure drawn to a different scale.

\section{Table 1. Association constants and total number of concanavalin $A$ binding sites per $B$. emersonii cell}

A molecular weight of 52000 was assumed for acetylated $\left[{ }^{3} \mathrm{H}\right]$ Con A (Gunther et al., 1973). The values listed were calculated from data presented in Fig. 1.

$\begin{array}{cccc} & \begin{array}{c}\text { High affinity } \\ \text { association } \\ \text { constant } \\ \left(\mathrm{M}^{-1}\right)\end{array} & \begin{array}{c}\text { Low affinity } \\ \text { association } \\ \text { constant } \\ \left(\mathrm{M}^{-1}\right)\end{array} & \begin{array}{c}\text { Total number of } \\ \text { Con A binding } \\ \text { sites per cell }\end{array} \\ \begin{array}{c}7.5 \times 10^{7} \\ \text { Non-induced }\end{array} & 3.5 \times 10^{5} & 4.3 \times 10^{7} \\ \begin{array}{c}\text { zoospores } \\ \text { Cells, } 15 \text { min } \\ \text { after induction }\end{array} & 1.2 \times 10^{7} & 2.3 \times 10^{5} & 3.0 \times 10^{7} \\ \begin{array}{c}\text { Cells, 30 min } \\ \text { after induction }\end{array} & 1.0 \times 10^{7} & 2.0 \times 10^{5} & 2.5 \times 10^{7} \\ \begin{array}{c}\text { Cells, } 45 \text { min } \\ \text { after induction }\end{array} & 8.0 \times 10^{6} & 1.6 \times 10^{5} & 2.1 \times 10^{7}\end{array}$

after induction (Table 1). The number of binding sites decreased concomitantly. At the completion of encystment, i.e. about $45 \mathrm{~min}$ after induction, there were $2 \cdot 1 \times 10^{7}$ specific binding sites per cell.

\section{Cells labelled with FITC-Con A}

Labelled zoospores exhibited intense fluorescence, including the flagellum sheath (Fig. $2 a$ ). The fluorescence intensity seemed to be more pronounced around the nuclear cap and the 'side body' complex (for a detailed structural description, see Lovett, 1975). Following the mixing of a zoospore suspension with germination solution, the resulting elongated cells showed somewhat weaker fluorescence. Labelled round cells also fluoresced and most of them were covered with many fluorescent spots (Fig. $2 b$ ). The number and size of these spots varied from cell to cell. Later, as cells became adhesive and tended to form clumps, the overall fluorescence intensity decreased.

In general, fixed cells fluoresced within a few minutes after application of FITC-Con A. 

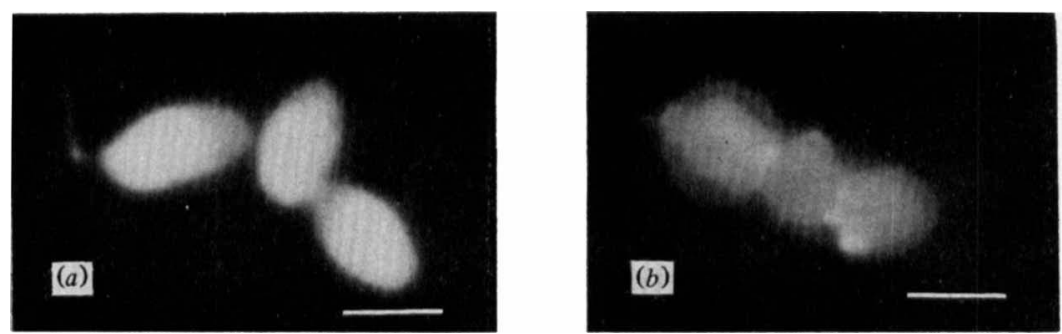

Fig. 2. Fluorescence micrographs of $B$. emersonii cells treated with fluorescein isothiocyanateconjugated concanavalin $\mathrm{A}:(a)$ non-induced zoospores; $(b)$ round cells fixed $15 \mathrm{~min}$ after induction. Bar markers represent $5 \mu \mathrm{m}$.

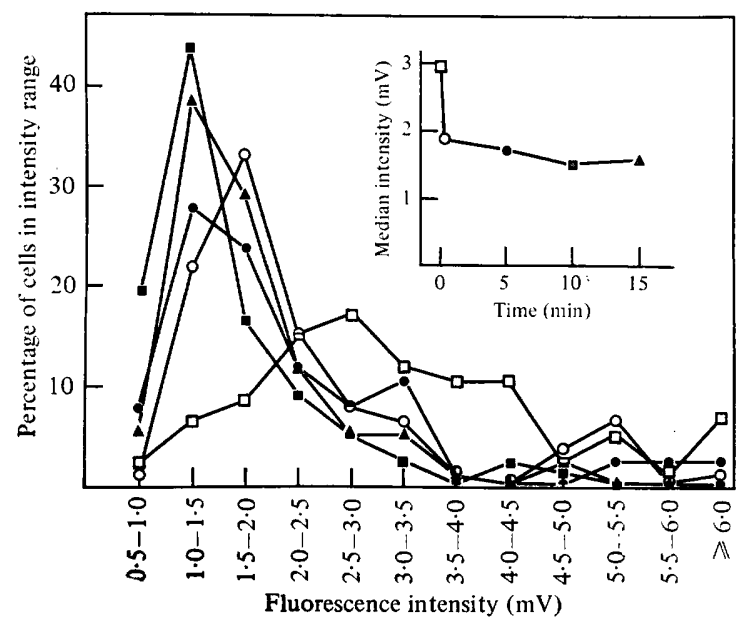

Fig. 3. Distribution of fluorescence intensity of $B$. emersonii zoospores during encystment. A total of 75 individual zoospores were randomly scored for each curve. The fluorescence intensity of individual cells was corrected for non-specific background fluorescence, determined as the average intensity from 25 control cells, in the presence of $\alpha$-methyl-D-mannoside and fixed at the same time as the individual cells being studied. The ordinate shows the percentage of the individually scored cells which fell within the intensity ranges. $\square$, Cells before induction; $\bigcirc$, cells fixed $15 \mathrm{~s}$ after induction; $\bigcirc$, cells fixed $5 \mathrm{~min}$ after induction; $\boldsymbol{\square}$, cells fixed $10 \mathrm{~min}$ after induction; $\boldsymbol{\Delta}$, cells fixed $15 \mathrm{~min}$ after induction. Inset: the median fluorescence intensity of the 75 individually scored cells before $(\square)$ and at the respective times after induction.

Extensive washing of cells with buffer did not affect the fluorescence intensity appreciably. The fluorescence intensity value from fixed, FITC-Con A-labelled cells, in the presence of $\alpha$-methyl-D-mannoside, was considered to be non-specific background fluorescence.

The fluorescence intensity of non-induced zoospores varied over a wide range (Fig. 3). Within the first 15 min after induction, elongated cells and those ready to encyst exhibited a fluorescence intensity which was weaker than that of non-induced cells, yet remained virtually constant; the intensity values of the majority of cells ranged from 1 to about $2 \mathrm{mV}$. Both round cells and germlings formed aggregates, and quantitative fluorescence measurements of single cells became impossible.

\section{Ultrastructural localization of Con A receptor sites}

Non-induced zoospores were densely labelled with ferritin-Con A which was distributed randomly over the cell surface and closely attached to the plasma membrane (Fig. $4 a$ ), including the sheath of the flagellum. The label density varied somewhat from cell to cell. In control samples, after application of $\alpha$-methyl-D-mannoside, only occasional ferritin 

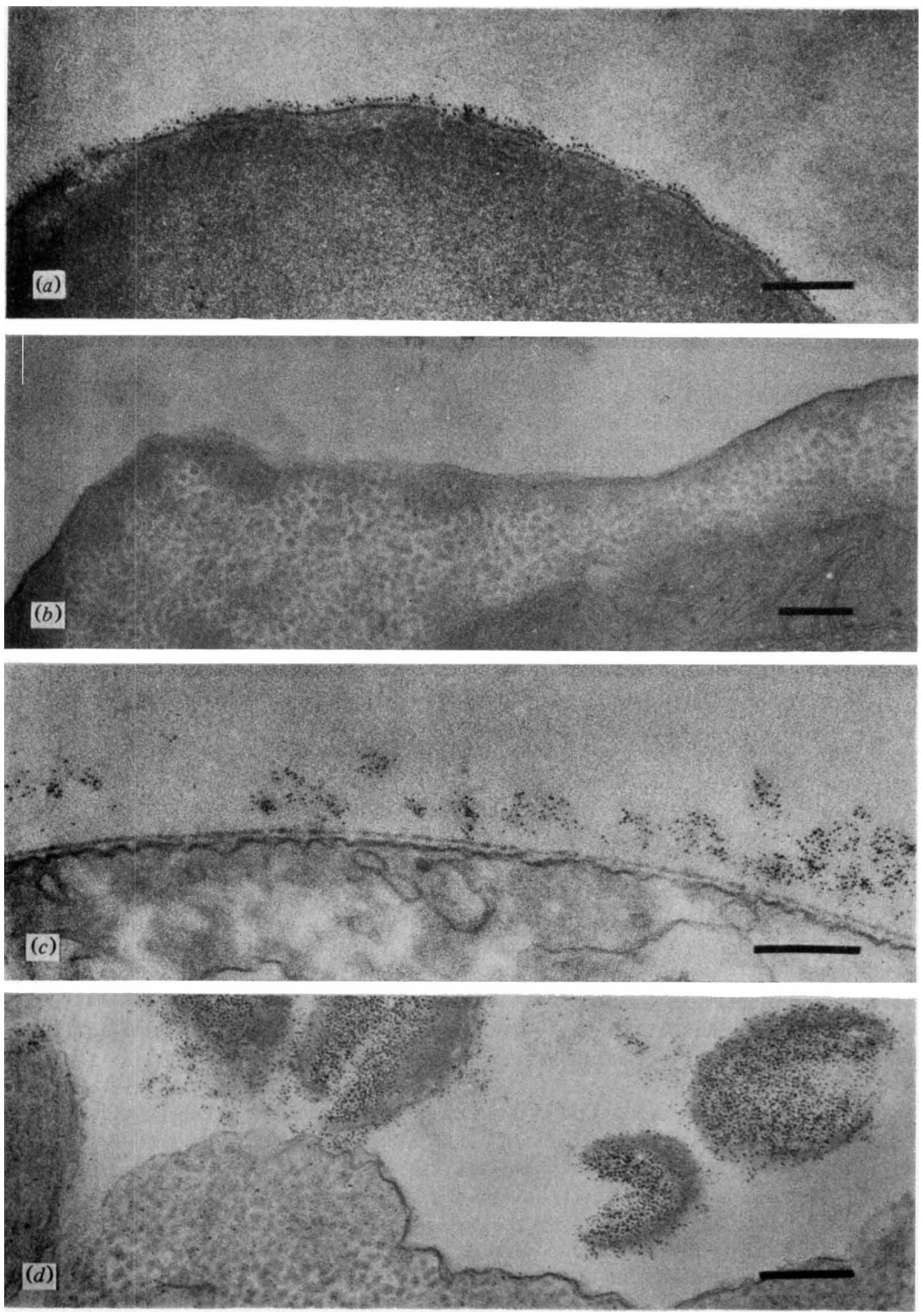

Fig. 4. Ultrastructural localization of concanavalin A binding sites of B. emersonii cells. (a) Noninduced zoospores; note the uniform distribution of ferritin molecules closely attached to the outer surface of the plasma membrane. $(b)$ Non-induced zoospores, in the presence of $0 \cdot 1 \mathrm{M}-\alpha-$ methyl-D-mannoside; only occasional ferritin molecules are attached to the cell surface. (c) Round cells; cells were induced and allowed to develop for $20 \mathrm{~min}$ before fixation and labelling; note ferritin molecules protruding into the extracellular region and forming patches. $(d)$ Zoospores were labelled with ferritin-conjugated concanavalin $\mathbf{A} ; \gamma$-particles were released from zoospores following concanavalin $\mathbf{A}$ application and the sample was fixed after labelling; note the densely labelled $\gamma$-particles especially along the inner kidney-shaped region. Bar markers represent $0 \cdot 2 \mu \mathrm{m}$. 
molecules were attached to the membrane surface (Fig. $4 b$ ). Immediately after induction, zoospores had a rather irregular shape and were labelled with ferritin particles closely attached to the cell membrane. However, the particle density appeared to diminish appreciably, and it remained consistently low on later oval-shaped zoospores. But in oval zoospores fairly large patches of ferritin-Con A were loosely associated with the cell surface and protruded into the extracellular space. Later, in round cells, the number of these patches increased to cover the peripheral extracellular region; however, the closely attached cell surface layer of ferritin labels became almost undetectable (Fig. $4 \mathrm{c}$ ). Some of these patches appeared to result from non-specific binding, since they could not be removed in control samples using $\alpha$-methyl-D-mannoside. Compared with round cells, ferritin patches associated with germlings became less pronounced and finally disappeared.

\section{DISCUSSION}

Major changes occur at the surface of $B$. emersonii zoospores while undergoing encystment preceding detectable de novo synthesis of protein and RNA (Soll \& Sonneborn, 1971). In the course of encystment, surface coat material is deposited by the fusion of vesicles (derived from $\gamma$-particles) with the plasma membrane (Myers \& Cantino, 1974). About 30 min after induction, the cells form germ tubes and this marks the completion of encystment.

Binding of Con $\mathrm{A}$ to the surface of zoospores during encystment was demonstrated by three different approaches: binding of radioactive Con $\mathbf{A}$, fluorescence microscopy and electron microscopy. During the entire course of encystment, Con A bound to the cell surface, although the binding characteristics varied appreciably. Moreover, at a given developmental stage, individual cells exhibited heterogeneity with respect to Con A binding as shown by fluorescence and electron microscopic experiments.

It appears that induction of synchronous development is accompanied by rapid physical alterations at the cell surface, perhaps the surface charge, membrane potential or fluidity. Observed cell volume changes (Truesdell \& Cantino, 1971) are presumably not related to variations in fluorescence intensity, as observed in our experiments, because the volume decreases by $43 \%$ between 5 and $15 \mathrm{~min}$ following induction, whereas the fluorescence intensity remains virtually constant.

We also found that $\mathrm{LiCl}$, which cannot induce encystment (Soll \& Sonneborn, 1972), produced practically the same fluorescence intensity distribution as in $\mathrm{KCl}$-treated cells. Synchronous development could be induced by $\mathrm{KCl}$ pulses as short as $2 \mathrm{~min}$ (Soll \& Sonneborn, 1972). Therefore, our results seem to support the notion that both kinds of ion induce similar physical alterations at the cell surface. Subsequent developmental processes are presumably inhibited by $\mathrm{LiCl}$.

During development from non-induced zoospores to round cells and germlings, Con A labelling experiments demonstrated the presence of two distinct surface labelling patterns, and also pronounced changes in binding affinity. This phenomenon may be interpreted in two ways. First, the original Con A binding sites participating in the formation of the closely attached layer may be removed during normal membrane turnover and then replaced by newly synthesized Con A binding receptors with a lower affinity. However, in B. emersonii, protein synthesis is not detectable during the short-lived encystment process. Thus, an alternative possibility is that during encystment pre-existing membrane components are modified to manufacture low affinity Con A receptors, in the absence of protein synthesis.

When the primary cell wall material is deposited, the closely attached Con A binding layer gradually becomes obscured. Meanwhile, the loosely associated ferritin-Con A patches continue to form. We propose that this pattern change is related to the fusion of $\gamma$-particle vesicles with the plasma membrane. These organelles have a high glycolipid content where glucosyl units are abundant (Mills \& Cantino, 1978; G. L. Mills, personal communication). Furthermore, preliminary experiments (Fig. $4 d$ ) indicated that $\gamma$-particles did exhibit a 
densely labelled surface of ferritin-Con A particles, following lysis of zoospores, release of $\gamma$-particles and subsequent exposure to Con A.

It is not known whether Con A binding sites play an active role in the developmental process described. Since Con A induces rapid zoospore lysis (Jen \& Haug, 1979), viable cells cannot be labelled and properly examined within the short time available during encystment. Nevertheless, the lysis experiments suggest that Con A receptors, in particular those characterized by the closely attached layer of label, maintain zoospore integrity. Preliminary electron microscopic studies demonstrate that this closely attached layer is not susceptible to pronase digestion contrary to the loosely associated patches which can largely be removed. The carbohydrate moiety of the closely attached layer perhaps protects the underlying proteins from pronase attack in the zoospore stage. Pronase-treated, non-induced zoospores are capable of completing normal encystment, if pronase is removed prior to induction. It appears that later developmental stages are sensitive to pronase digestion as shown by retarded germination following pronase treatment at the round cell stage. Further experiments are necessary to clarify the physiological role, if any, of lectin receptors during zoospore development.

We thank Dr J. L. Wang for valuable discussions and Dr J. E. Wilson for allowing the use of the Leitz microscope. We are indebted to Dr E. C. Cantino for the B. emersonii strain. This work was supported by US-DOE Contract EY-76-C-02-1338.

\section{REFERENCES}

Gremo, F., KobILer, D. \& Barondes, S. H. (1978). Distribution of an endogenous lectin in the developing chick optic tectum. Journal of Cell Biology 79, 491-499.

Gunther, G. R., WANG, J. L., Yahara, I., CuNNINGHAM, B. A. \& Edelman, G. M. (1973). Concanavalin A derivatives with altered biological activities. Proceedings of the National Academy of Sciences of the United States of America 70, 1012-1016.

JEN, C. J. \& HAUG, A. (1979). Concanavalin A induced lysis of zoospores of Blastocladiella emersonii. Experimental Cell Research 120, 425-428.

LoveTT, J. S. (1975). Growth and differentiation of the water mold Blastocladiella emersonii: cytodifferentiation and the role of ribonucleic acid and protein synthesis. Bacteriological Reviews 39, 345-404.

Mills, G. L. \& Cantino, E. C. (1978). The lipid composition of the Blastocladiella emersonii $\gamma$ particle and the function of the $\gamma$-particle lipid in chitin formation. Experimental Mycology 2, 99109.

Myers, R. B. \& Cantino, E. C. (1974). The gamma particle. In Monographs in Developmental Biology, vol. 8, pp. 15-20. Edited by A. Wolky. New York: S. Karger.

Rosenthal, H. E. (1967). A graphic method for the determination and presentation of binding parameters in a complex system. Analytical Biochemistry 20, 525-532.
Sharon, N. \& Lis, H. (1975). Use of lectins for the study of membranes. In Methods in Membrane Biology, vol. 3, pp. 147-200. Edited by E. D. Korn. New York: Plenum Press.

Soll, D. R. \& Sonneborn, D. R. (1971). Zoospore germination in Blastocladiella emersonii: cell differentiation without protein synthesis? Proceedings of the National Academy of Sciences of the United States of America 68, 459-463.

Soll, D. R. \& SonNEborn, D. R. (1972). Zoospore germination in Blastocladiella emersonii. IV. Ion control over cell differentiation. Journal of Cell Science 10, 315-333.

Soll, D. R., BramberG, R. \& Sonneborn, D. R. (1969). Zoospore germination in the water mold, Blastocladiella emersonii. I. Measurement of germination sequence of subcellular morphological changes. Developmental Biology 20, 183217.

SPURR, A. R. (1969). A low-viscosity epoxy resin embedding medium for electron microscopy. Journal of Ultrastructure Research 26, 31-43.

Truesdell, L. C. \& Cantino, E. C. (1971). The induction and early events of germination in the zoospore of Blastocladiella emersonii. Current Topics in Development Biology 6, 1-44.

WEEKS, G. (1975). Studies of the cell surface of Dictyostelium discoideum during differentiation: the binding of $\left.{ }^{[25} \mathrm{I}\right]-$ Con $A$ to the cell surface. Journal of Biological Chemistry 250, 6706-6710. 